DIW BERLIN

Discussion Papers

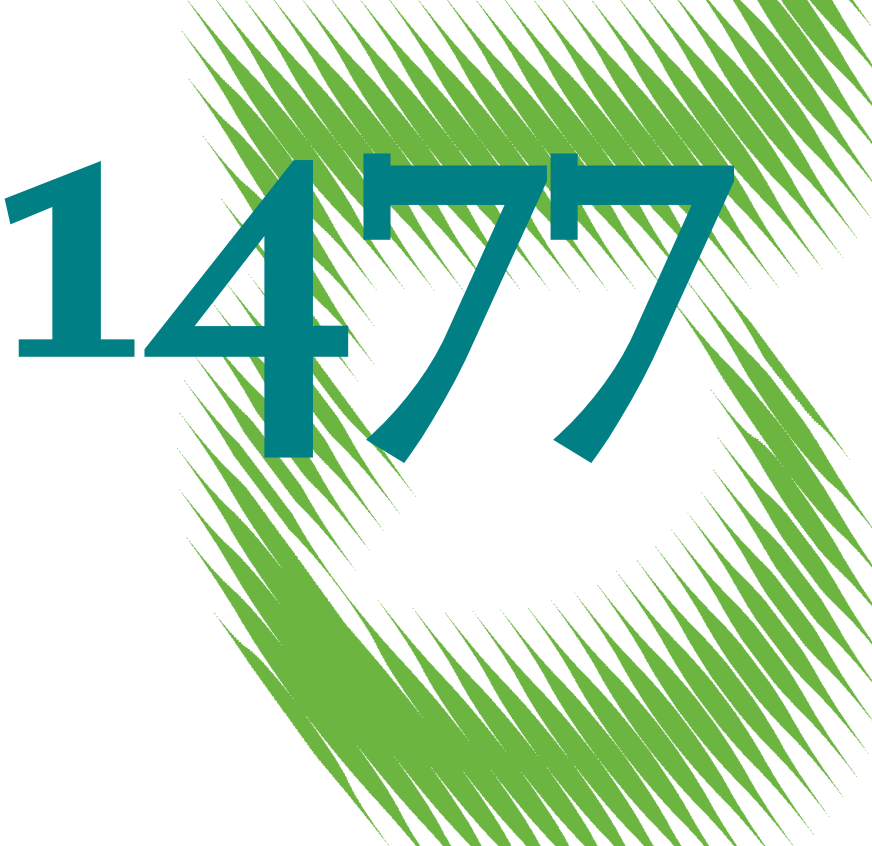

War, Housing Rents, and Free Market: A Case of Berlin's Rental Housing Market during the World War I 
Opinions expressed in this paper are those of the author(s) and do not necessarily reflect views of the institute.

IMPRESSUM

(C) DIW Berlin, 2015

DIW Berlin

German Institute for Economic Research

Mohrenstr. 58

10117 Berlin

Tel. +49 (30) $89789-0$

Fax +49 (30) $89789-200$

http://www.diw.de

ISSN electronic edition 1619-4535

Papers can be downloaded free of charge from the DIW Berlin website:

http://www.diw.de/discussionpapers

Discussion Papers of DIW Berlin are indexed in RePEc and SSRN:

http://ideas.repec.org/s/diw/diwwpp.html

http://www.ssrn.com/link/DIW-Berlin-German-Inst-Econ-Res.html 


\title{
War, housing rents, and free market: A case of Berlin's rental housing market during the World War I
}

\author{
Konstantin A. Kholodilin*
}

May 4, 2015

\begin{abstract}
Before the World War I, the urban rental housing market in Germany could be described as a free and competitive market. The government hardly interfered in the relationships between the landlords and tenants. The rents were set freely. During the World War I, the market was hit by several violent shocks. The outbreak of the war led initially to a huge outflow of men from cities to the fronts. Towards the end of the war, the cessation of construction as well as an inflow of workers and mustered out of service soldiers produced an acute housing shortage. Using a unique data set of asking rents extracted from the newspaper announcements, we constructed a monthly time series of rents in Berlin over 1909-1917. This variable is employed to measure the effects of demand and supply shocks on different segments of housing: from small dwellings for poor to large apartments for rich. The analysis shows a decline of rents (especially of the cheap dwellings) in the first half of the war, followed by a moderate increase. This stands in marked contrast to a steady and strong increase of the overall price level.
\end{abstract}

Keywords: housing rents; announcements; World War I; Berlin.

JEL classification: C10; C52; C53; E32.

\footnotetext{
II would like to thank Claus Michelsen and Dirk Ulbricht for their helpful comments, Dmitry Chervyakov and Niklas Dornbusch for their great research assistance, and last but not least Gabriele Knopf for the historical statistical data. The standard disclaimer applies.

*Research associate, DIW Berlin, Mohrenstraße 58, 10117 Berlin, Germany, e-mail: kkholodilin@diw.de.
} 


\section{Contents}

1 Introduction 1

2 Data $\quad 4$

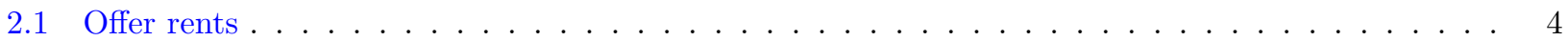

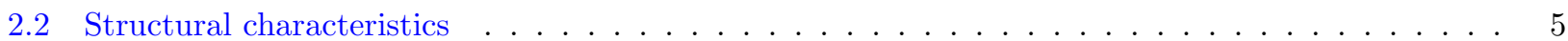

2.3 Locational characteristics $\ldots \ldots \ldots \ldots \ldots \ldots \ldots \ldots \ldots \ldots$

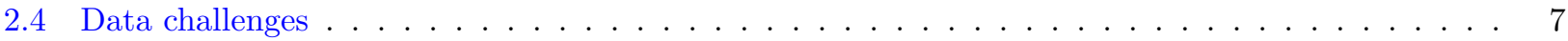

$\begin{array}{llr}3 & \text { Empirical approach } & 9\end{array}$

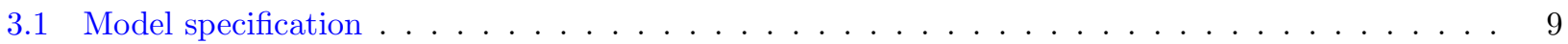

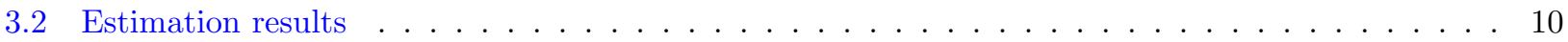

4 Evolution of Berlin's rent before and during the World War I 12

5 Conclusion $\quad 15$

$\begin{array}{lr}\text { References } & 15\end{array}$

$\begin{array}{lr}\text { Appendix } & 18\end{array}$ 


\section{List of Tables}

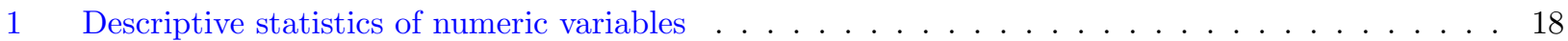

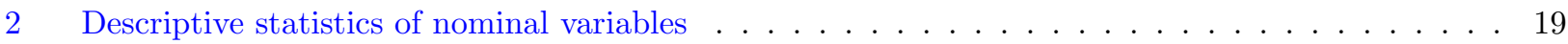

3 Estimation results of OLS and quantile regressions $\ldots \ldots \ldots \ldots \ldots \ldots$

\section{List of Figures}

1 Housing market shocks during the World War I . . . . . . . . . . . . . . . . 21

2 Housing vacancy rate in Berlin, $1872-1939 \ldots \ldots \ldots \ldots \ldots \ldots \ldots$

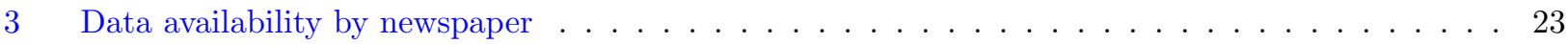

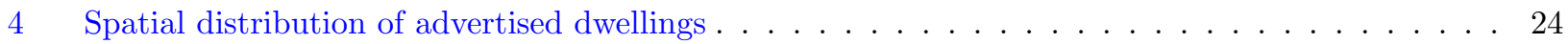

$5 \quad$ Isochrones of underground, city, and suburban railways for Alexanderplatz, 1912-1914 _ . . . . 25

6 Distribution of Berlin's dwellings by number of habitable rooms: official data and newspapers . . 26

$7 \quad$ Comparison of housing rents by apartment size: official data and newspapers $\ldots \ldots \ldots$. . . . . 27

8 Distribution of Berlin's rental dwellings by districts: official data and newspapers . . . . . . . 28

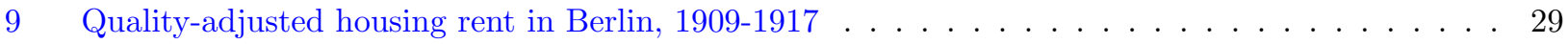

10 Dynamics of quality-adjusted housing rent in Berlin by segments, 1909-1917 . . . . . . . . . . 30

11 Geographical distribution of quality-adjusted rent in Berlin, July 1914 . . . . . . . . . . . . 31 


\section{Introduction}

A century ago like nowadays the rental housing played a dominant role in large German cities. Its share in the overall housing stock attained $80-97 \%{ }^{1}$ So, the vast majority of city inhabitants were tenants.

Before the World War I, the government avoided intervening in the housing sector and confined itself to some minimal regulation regarding the quality of rental housing (sunniness, dryness, size). ${ }^{2}$ The 1900 German Civil code provided a complete freedom of contractual relations in the housing market. ${ }^{3}$ This implied that the relations between the tenants and landlords were regulated exclusively by the contracts they concluded without interference of a third party.

This situation changed radically during World War I, when the housing market was hit by several violent demand and supply shocks, as illustrated in Figure 1.

Initially, a negative demand shock took place. This was related to the departure of men to the front along with the forced return of many wives to their parental households as well as outflow of the enemy aliens reduced the demand for housing (downward demand curve shift, new equilibrium in point $B$ ).

However, later on, came a strong negative supply shock. It was caused by the cessation of housing construction/renovation. The construction of dwellings in Berlin strongly decelerated already in the first year of the war and came to an almost complete stop in 1916. While in 1913, 4519 new dwellings were completed, in 1916 this figure went down to 53 and in 1918 even to $13 .{ }^{4}$ This can be described as a leftward shift of supply curve and so the displacement of the equilibrium from the pre-war equilibrium point $A$ to point $C$.

Finally, a positive demand shock occurred. Already during the war, new labor began to come into the cities, especially, to the centers of the armament industry. An already strained situation deteriorated even more when the soldiers started to return back home and the number of marriages suddenly increased. ${ }^{5}$ As the marriage

\footnotetext{
${ }^{1}$ Brander (1984), p. 81.

${ }^{2}$ For instance, in some German cities, minimum standards of housing area per person varying between 3 and 4 square meters existed. However, even these standards, which from current perspectives seem to be insufficient, were regularly violated; see Brander (1984), p. 102-103. In Berlin, since October 1911 the following norm was prescribed: for each person older than 10 years there should be available at least $10 \mathrm{~m}^{3}$ space and $4 \mathrm{~m}^{2}$ surface, while for each younger person - at least a half of it; see Praktische Wohnungsfürsorge, Berliner Tageblatt und Handels-Zeitung, 4th of August 1912, p. 51.

${ }^{3}$ So, $\S 565$ of the 1900 German Civil code stipulated that a housing rental contract without definite duration could be terminated by the landlord, depending on rental payment frequency, at the end of the current payment period (week or month). In addition, landlords might immediately evict a tenant, if the latter violated the contractual conditions, particularly if subletting the dwelling without landlord permission (\$553) or did not pay rent, on time, for at least two subsequent periods (\$554). See Achilles et al. (1909).

${ }^{4}$ The data are compiled from different issues of Berlin's statistical yearbooks.

${ }^{5}$ For a comprehensive analysis of the housing problem during and after the World War I in all the war participant countries in general and in Germany in particular see International Labour Office (1924).
} 
statistics show, in the last two war years, the number of marriages in Berlin doubled compared to those in the first two years and was $25 \%$ more than in the pre-war period. ${ }^{6}$ In addition, after the war, the refugees from the territories ceded by Germany to France and Poland as well as Russian emigrants fleeing from the Civil war, flooded Berlin. As a result, the shortage of dwellings became acute, which should have constituted an upward pressure on rents (see point $D$ in Figure 1).

The resulting changes in the Berlin's housing market pressure can be illustrated with Figure 2. It shows the evolution of housing vacancy rate in Alt-Berlin over one hundred years: between 1841 and $1939 .^{7}$ The vacancy rate is measured in \%o, that is, the number of vacant apartments per 1000 of available apartments. It started to increase in 1914, attained its peak in 1916, and then began to decrease in 1917 . In the last year of war, it approached the "critical" threshold of 30\%, beyond which the dwellings are assumed to become scarce. Interestingly, the increase in vacancy rate observed in the first war years was not extraordinary high. The crisis of the housing market in the late 1880s saw an even higher increase. However, the housing shortage that followed the war was extreme as the figures for Groß-Berlin show. ${ }^{8}$

Attempting to avoid social turmoils, German authorities actively intervened in the housing market. The first measure taken already during the war was to introduce the protection of tenants from eviction. ${ }^{9}$ Later, after the war was over, rent controls were introduced. In Germany, Prussia was one of the first federal states that put in action rent controls and in December 1919 froze the housing rents. ${ }^{10}$ In 1922 , this measure was introduced at the national level. ${ }^{11}$ It concerned only the so-called "old housing" (Altbauwohnungen), that is, the housing built before 1918. However, given a virtual cessation of construction activity during the war, virtually all the housing stock belonged to that category. The rent in these houses was fixed at the July 1, 1914, levels. It was called "legal rent" (gesetzliche Miete), or "peacetime rent" (Friedensmiete), and could not be freely increased by the landlords. Any rent adjustments could only be promulgated by the authorities.

\footnotetext{
${ }^{6}$ See various issues of the statistical yearbooks of Berlin published between 1912 and 1922.

${ }^{7}$ The data are taken from Silbergleit (1913) and Silbergleit (1920). They refer to the so-called Alt-Berlin, which was about 13 times smaller than the modern Berlin in terms of territory and about two times smaller in terms of population. The city got its actual shape after the administrative reform of April 27th, 1920, when Alt-Berlin with merged with many neighboring communities to form the so-called Groß-Berlin.

${ }^{8}$ The 1913 and 1915 figures for Groß-Berlin are approximations obtained for six (Alt-Berlin, Charlottenburg, Neukölln, Schöneberg, Wilmersdorf, and Steglitz) and eight (plus Lichtenberg and Spandau), respectively, largest districts that accounted for more than $85 \%$ of total housing stock in Groß-Berlin.

${ }^{9}$ Bekanntmachung zum Schutze der Mieter. 26.07.1917, RGBl, p. 659-660. ("Act on eviction protection of tenants") and Bekanntmachung zum Schutze der Mieter. 23.09.1918, RGBl, p. 1140-1143. ("Act on eviction protection of tenants").

10 "Anordnung des Ministers für Volkswohlfahrt, betreffend Einführung einer Höchstgrenze für Mietzinssteigerungen". 9.12.1919, GS, p. 187 ("Ordinance of the Minister of Welfare concerning the introduction of an upper bound for housing rent increases").

${ }^{11}$ Reichsmietengesetz. 24.03.1922, RGBl, p. 273-279 ("Reich's law on housing rent").
} 
Thus, the World War I introduced dramatic and long-lasting changes in terms of housing policy. Since then rental housing market was never free of state regulation. The regulation degree changed wavelike in response to the changing conditions, but the state kept intervening in the relations between the tenants and landlords. ${ }^{12}$

Therefore, the World War I can be considered as an ideal natural experiment to test the sensitivity of reaction of the rental housing market to the supply and demand shocks: During most of the period the market was free and the shocks were especially large.

The aim of this paper is to demonstrate that without government regulations restricting the freedom of market participants, the rental housing market was very sensitive to both the supply and demand shocks. The idea behind this is that the market was competitive because of the large number of suppliers who possessed no market power and readily adjusted the rent for dwelling units and their supply to the changing market conditions. ${ }^{13}$

To the best of our knowledge, this is the only study investigating the effects of the World War I upon the housing rent. The impact of the war on the rent was recognized already by the contemporaries. For example, Kaeber (1921), p. 458 cites the rent decreases in Berlin in response to the negative demand shock. However, this is usually done in an informal way without providing quantitative evidence.

In this paper, we take advantage of a unique data set that was never used in the literature before. The literature relying upon historical microdata on housing rents is very thin. We are aware of only two such studies, both referring to the USA. Rees (1961) apparently was the first to employ the data asking rents collected from newspapers estimate rents in six US cities between 1890 and 1914. The second and the most recent study using the historical offer rents from newspaper advertisements is that of Margo (1996). His data set contains approximately 1000 observations and covers rental apartments in New York over the period 1830 to 1860. Margo uses the data to estimate hedonic rental price and investigate its determinants.

The paper is structured as follows. Section 2 describes our unique data set, which comprises the information contained in the real-estate advertisement from two large Berlin's newspapers. In section 3 , several econometric models are presented that are used to obtain the monthly time series of the quality-adjusted housing rent in Berlin in 1909-1917. In section 4, the afore mentioned hypotheses are tested using the time series of rents.

\footnotetext{
${ }^{12}$ For a regulation index in the German rental housing market see Kholodilin and Ulbricht (2014).

${ }^{13}$ For a definition of a competitive housing market see Olsen (1969).
} 
Finally, section 5 concludes.

\section{Data}

\section{$2.1 \quad$ Offer rents}

The data on rents in Germany overall and in Berlin in particular before the World War I are very poor. ${ }^{14}$ We were able to find only two historical time series of rents in Berlin. The first one is the annual series over the period 1841-1895 from Reich (1912), which is based on the rental tax (Mietsteuer) data. The second is that in Ascher (1917) that covers the period from 1880 through 1910. It has a five-year frequency and ends, unfortunately, before our period of interest. The data of official statistics as published in the statistical yearbooks of Berlin's statistical office are even worse: no time series is available. There is only one observation for 1907. For the period 1908-1916, only the frequency tables for rent classes could be found. But even these data have missing observations in 1911, 1914-1915 — the most interesting years in our analysis.

Therefore, we decided to construct our own time series of housing rents for Berlin. To do this we took advantage of the announcements of apartments placed in two Berlin's most popular advertizing papers: Berliner Tageblatt und Handels-Zeitung (BTB) and Berliner Lokalanzeiger (BLA). ${ }^{15}$ These contain both rents and various characteristics of housing to let: location, size, equipment.

The sample covers a period from January 1909 through December 1917. The data set includes about 14,000 observations, which corresponds to about 130 advertisements per month. Figure 3 depicts the distribution of announcements by year, newspaper, and availability of rent information. It can be seen that the number of advertisements fluctuated strongly over time. Moreover, BLA contained many more housing ads than BTB.

The large majority of announcements contain no numerical data on rents: only between 10 and $25 \%$ include the rent figures. However, given that the manual extraction of information from the advertisements is a very time consuming exercise, we included in our data set mainly announcements with rents. The share of observations without rents in our data set approaches $35 \%$.

\footnotetext{
${ }^{14}$ See, e.g., Bernhardt (1998) pp. 157.

${ }^{15}$ BTB was founded in $1871 / 1872$ by Rudolf Mosse and attained 230,000 copies on the eve of the World War I, while BLA was founded in 1883 by August Scherl and achieved in 1910 300,000 copies, see Dussel (2011) p. 87 and Stöber (2014), p. 257, respectively.
} 


\subsection{Structural characteristics}

The rent depends both on structural (size and quality) and on the locational characteristics of the dwellings. Tables 1 and 2 report the descriptive statistics on the numerical and nominal structural characteristics, respectively.

At that time, no data on floor area of apartment were reported in the newspaper announcements. Therefore, the size of an apartment could only be measured by the number of rooms.

\subsection{Locational characteristics}

Georeferencing the announced dwellings Most of the announcements contain the street name and the house number (98.7\% of all dwellings). This information was used to georeference each dwelling, that is, assign to it its geographical coordinates. Other important sources of geographical information that were taken advantage of include:

- Berliner Adreßbuch (Berlin's address book) for 1922. It contains a complete list of houses in Groß-Berlin and had been published on an annual basis. We chose the 1922 edition due to several reasons. First, it was published just a few years after the end of our sample period. Second, this short time span was characterized by violent events, including hyperinflation. Taken together it means that very few houses and streets were built between 1917 and 1922. So, the address changes during that period should have been minor. Third, it was the first edition that contained the alphabetic street register for whole Groß-Berlin and not only Alt-Berlin as in previous editions.

- Berliner Straßenlexikon, which is a list of Berlin's historical street names up to now. It contains information on when the street was renamed, included into another street, or abolished: http://berlingeschichte. de/strassen

- RBS-Adressdienst (Address Service) of the Senatsverwaltung für Stadtentwicklung und Umwelt (Senate Department for Urban Development and the Environment), which is the most up-to-date and complete official list of Berlin's addresses including information on the geographical coordinates and administrative district, to which each particular address belongs: http://www.stadtentwicklung.berlin.de/ 
geoinformation/geodateninfrastruktur/de/geodienste/rbs_adressauskunft.shtml

- HistoMap, which is an online collection of the digitalized and georeferenced historical maps of Berlin starting from the Straube's 1910 map of Alt-Berlin to the modern map: http://www.histomapberlin. de/de/index.html

Quite a few street names in Berlin repeat in different districts. ${ }^{16}$ But the district names are mentioned just in few announcements. So, to find house coordinates in a correct street we made a convention that in case of missing district name, the street has to be located in districts closer to the center. Additional geographical information contained in the announcements (e.g., "close to the Zoo", "5 minutes walk from Bellevue station", or "in front of the old botanical garden") was used to improve the georeferencing.

Figure 4 shows the spatial distribution of georeferenced advertised dwellings in Berlin. The dwellings are not evenly distributed over the whole city's area. They are mostly concentrated in the west and in the central districts. The number of announced dwellings decays rapidly towards the periphery.

Among other things, the resulting coordinates were used to assign dwellings to districts. In 20th century, the number and names of Berlin's districts underwent several major changes. Here, we are using the administrative division corresponding to the 1920 Groß-Berlin reform, which provided for 20 districts.

Accessibility One of the important factors determining the rent is the transport connection to the central business district (CBD). Typically, it is measured as a direct distance to the CBD. However, this approach does not take into account the real accessibility depending on the transportation network in place. Therefore, in order to measure it we use the travel time. ${ }^{17}$ It is computed using the coordinates of the stations of underground, city, and suburban railways ${ }^{18}$ as well as travel times between each pair of adjacent stations computed from the time schedules. The travel times for city and suburban railways were taken from Königliche Eisenbahndirektion Berlin (1912) — a schedule book published in 1912. It contains information on 176 stations and connecting them 23 lines. We use only travel times that were valid during the working days and represent the average time across the whole day. The travel times between the 46 underground stations are borrowed from a subway

\footnotetext{
${ }^{16}$ For example, there used to be 28 Bahnhofstrasse and 25 Berliner Strasse in the Groß-Berlin. Overall, in the period under inspection, among about 6000 streets there were over 1900 streets with repeating names, which makes up roughly one third. Our sample includes 1298 street names, among them 425 are repeating ones, i.e., also about one third.

${ }^{17}$ Similar indicator is used to estimate the change in land gradient for historical land values in Berlin from 1890 to 1936 in Ahlfeldt and Wendland (2011).

${ }^{18}$ In 1914, the underground, city, and suburban railways in Berlin accounted for almost one fourth of the 955 million persons that were conveyed by all the means of public transportation, as can be calculated from Silbergleit (1920), p. 505 .
} 
map from 1914. Thus, we can approximate the transport connections that were prevailing in the middle of our sample. The shortest travel times from each station to Alexanderplatz are computed using the igraph package for $\mathbf{R}{ }^{19}$ A grid of $900(=30 \times 30)$ points is constructed. From each point, a walking time in minutes to each station is computed as the Great circle distance multiplied by 60 minutes and divided by the walking speed of $4 \mathrm{~km} /$ hour. This speed is assumed, for example, in Leyden (1933), p. 121 and Riedel (1911), p. 27. Then, from each point the shortest travel time (walking and riding the railways) to Alexanderplatz is calculated. Afterwards, the travel times are spatially interpolated for 227,474 points using ordinary kriging with a spherical semivariogram model as implemented in package gstat for $\mathbf{R} .{ }^{20}$ Figure 5 depicts the resulting isochrones, that is, the lines of equal travel time. It can be seen that they are very far from resembling the concentric circles that would result from employing a mere Great circle distance to the CBD as a proxy for accessibility. To a large extent the difference is due to existence of the radial lines of the suburban railways.

\subsection{Data challenges}

A few caveats concerning the quality and availability of the data should be made.

- Cheap apartments are underrepresented in our sample. Figure 6 shows that compared to the results of a housing survey, conducted on May 31, 1918 by the city's statistical office, the announcements of small (up to 2 habitable rooms) and middle apartments (between 3 and 4 habitable rooms) are underrepresented, while those of large apartments (between 5 and 7 habitable rooms) are overrepresented. ${ }^{21}$ Such a lack of representativeness can be explained by two related reasons. First, the newspaper housing announcements were mainly addressing higher income persons. This is especially the case of Berliner Tageblatt, whose announcements reflect the higher segments of the rental housing markets. ${ }^{22}$ Second, the poor people must have searched for information about housing from other sources than newspapers. It was most probably related rather to the cost of purchasing newspaper than to their ability to read. For by the beginning of 20th century, the literacy rate should have been quite high in Germany. ${ }^{23}$ Not accounting for the structural misalignment of our data set can lead to exaggerated average rent estimates. According to Ascher

\footnotetext{
${ }^{19}$ See http://igraph.org/r/.

${ }^{20}$ See http://www.gstat.org/ and Pebesma (2014).

${ }^{21}$ The official statistics at that time defined the habitable rooms as normal rooms plus chambers, maid's rooms, and alcoves.

${ }^{22}$ As the newspaper acknowledges itself: "Berliner Tageblatt... hat allein in Groß-Berlin über 115000 feste Abonnenten, die meist den gutsituierten Kreisen angehören", BTB, June 7, 1914, p. 60.

${ }^{23}$ Already in 1871, the literacy rate in Germany attained 88\%, see Stöber (2014), p. 312
} 
(1917), the average annual rent in Alt-Berlin in 1910 was 474, 1657, and 592 marks per apartment without commercial space, with commercial space, and overall (including both these categories), respectively. In our data set, the average annual rent for Alt-Berlin 1910 is about 1014 marks. However, if we account for the underrepresentation of smaller apartments and compute a corrected rent using the actual distribution of housing stock by habitable rooms, ${ }^{24}$ we arrive at 526 marks for 1910 , which is close to the Ascher's average figure for dwellings with and without commercial spaces. Nevertheless, the underrepresentativeness of cheap dwellings should not pose problems when estimating quality-adjusted rents by regression. Firstly, because all size classes of apartments are present in our sample. Secondly, because, when apartment size is controlled for, the rents reported in newspapers are very close to the official estimates as Figure 7 shows. It compares the official and announcement-based average rents in 1910 computed for different sizes for apartments, varying from 1 through 9. As official data we use the average rents reported in Ascher (1917), p. 108, Table 3. The similarity is striking. Although official rents are below the announcement-based rents for apartments with less than 4 rooms, the former are above the latter for larger apartments. However, these differences are rather small.

- Some districts are underrepresented as can be seen in Figure 8. This can be related to the previously mentioned challenge, for the among the underrepresented districts are mainly those with a large share of cheap apartments. Another reason for being underrepresented is a big distance from the central business district. Finally, the overrepresented districts (Schöneberg, Wilmerdorf, and Charlottenburg) were centers of building activity in the pre-war period and therefore possessed many new dwellings to be let out.

- The values of many structural variables are missing for certain apartments. This can be explained by two reasons: Either the corresponding dwelling was of a lower quality and did not have this characteristic or its availability was so self-evident that the lessor did not mention it in order to save money. Examples of such variables include the availability of kitchen, chamber, or corridor. As Table 5 shows, the share of small apartments with kitchen, chamber, and corridor is substantially higher than that of large apartments. This does not mean, of course, expensive apartments had no kitchen or corridor. Therefore, in advertisements of large apartments, often the complete list of such default characteristics is replaced by a short expression

\footnotetext{
${ }^{24}$ The distribution of Alt-Berlin's housing stock by size was taken from Silbergleit (1920), p. 11, Table 20. It corresponds to the results of the housing survey conducted on May 31, 1918.
} 
"aller Komfort" (all comfort). By contrast, for cheap apartments, where such facilities were frequently missing, it was important to stress their availability. This issue is known in the literature as "censored regressors". 25

- The number of usable observations, that is, those containing both rent and number of rooms, is relatively small for some periods. It is especially true towards the end of the sample: starting in the second half of 1917, very few rental housing advertisements were published. Most likely this had to do with their growing scarcity of dwellings. The turnover of rental apartments decreased and so fewer dwellings were advertised in the press.

- The rents published in the announcements are, of course, offer rents. A realized, or transaction, rent could deviate from that indicated in the advertisement. However, this deviation is very small as Figure 7 indicates.

\section{Empirical approach}

\subsection{Model specification}

In this section, we estimate the dynamics of quality-adjusted rents in Berlin in 1909-1917. The quality adjustment is conducted using hedonic regression of the following form:

$$
p_{i}=\alpha+X_{i}^{\prime} \beta+\sum_{j=1}^{J} \gamma_{j} I_{j i}^{D}+\sum_{k=1}^{K} \delta_{k} I_{k i}^{T T}+\sum_{t=1}^{T} \theta_{t} I_{t i}^{P}+u_{i}
$$

where $p_{i}$ is the annual rent for $i$-th apartment in marks; $X_{i}$ is the vector of structural characteristics of the housing; $I_{j}^{D}$ are the district dummies; $I_{k}^{T T}$ are the travel time dummies; $I_{t}^{P}$ are the time dummies, $\alpha, \beta, \gamma$ 's, $\theta$ 's, and $\delta$ 's are the parameters; and $u_{i}$ is the error term. The time dummies are defined as year and month. For example, a time dummy for August 1914 is defined as:

$$
I_{t}^{1914: 08}= \begin{cases}1 & \text { if } t=\text { August } 1914 \\ 0 & \text { otherwise }\end{cases}
$$

\footnotetext{
${ }^{25}$ As shown in Rigobon and Stoker (2009), this can lead to biased parameter estimates.
} 
The regression is estimated by the ordinary least squares (OLS) method. The estimation results are in column (1) of Table 3 .

In order to test the rent dynamics of different market segments (cheap vs. expensive apartments), we apply a semi-parametric quantile regression (QR) method. ${ }^{26}$ Under this technique, the quantiles of the conditional distribution of the dependent variable are expressed as functions of explanatory variables. The quantile regression can be formulated as:

$$
Q_{\tau}\left(p_{i} \mid X_{i}^{\prime}, I_{j}^{D}, I_{k}^{T T}, I_{t}^{P}\right)=X_{i}^{\prime} \beta_{\tau}+\sum_{j=1}^{J} \gamma_{\tau, j} I_{j i}^{D}+\sum_{k=1}^{K} \theta_{\tau, k} I_{k i}^{T T}+\sum_{t=1}^{T} \delta_{\tau, t} I_{t i}^{P}+u_{\tau, i}
$$

where $Q_{\tau}$ is a $\tau$-th quantile of $p_{i}$ conditional on the explanatory variables, with $0<\tau<1$. Thus, the quantile regression allows estimating the effect of explanatory variables for the whole distribution, that is, at each quantile of dependent variable, $p_{i}$. Two additional advantages of the quantile regression are that it is robust to the outliers and imposes no assumptions on the exact distribution form of the error term.

\subsection{Estimation results}

Before we embark on the estimation, the model specification should be determined. It is obtained using an automatic model selection approach. ${ }^{27}$ The idea behind this approach is to generate all possible model specifications. The fitness of each model is characterized by a corresponding information criterion (IC) value. The model with the lowest IC is treated as the "best model". An exhaustive fitting, however, may be prohibitive, given a large sample size and a relatively big number of explanatory variables to test. Indeed, the number of all possible combinations is $2^{n}$, where $n$ is the number of covariates. In our case, there are $n=22$ potential explanatory variables and so the candidate set should contain 4,194,304 models. Given that some of the variables are categorical ones with numerous distinct values (e.g., District or Year/month variables), the exhaustive search would be too time consuming. Therefore, a genetic algorithm is applied, which allows finding the best model without fitting all possible models. The optimal model was obtained by running five independent genetic algorithms and finding their consensus.

\footnotetext{
${ }^{26}$ See Koenker and Bassett (1978) and Koenker (2005) for a formal exposition of the quantile regression and especially Koenker (2012) for its $\mathbf{R}$ implementation in form of a package quantreg.

${ }^{27}$ The model selection was carried out using an $\mathbf{R}$ package glmulti. For more details on the package and the underlying methodology see Calcagno and de Mazancourt (2010).
} 
The estimation results of OLS and quantile regressions for the best model are reported in Table 3. For OLS, the heteroskedasticity and autocorrelation consistent standard errors were computed using the Newey-West robust covariance matrix. For quantile regression, the standard errors were obtained using bootstrap.

Structural characteristics The number of rooms and square of this number have positive and significant coefficients for all models. It is not surprising, given that the dependent variable is total rent per year. The positive sign of squared number of rooms variable, Room_sq, means that in the larger dwellings space is more expensive.

The coefficients of loggia and maid's room are negative in OLS model. In a more robust model — quantile regression — both coefficients are positive and significant, which appears to be more intuitive. The availability of garden has in most cases positive and significant coefficient estimate. The availability of electricity and warm water contributes positively to the asking rent. The rent effects of different types of heating vary a lot, the vapor heating being the highest valued (the default value is unknown type of heating, which includes in many cases the non availability of heating). The premium for furniture varies between 314 and 464 mark per year, which makes up 30-40\% of the average annual rent in our sample. The availability of a lift is expected to be rewarded with $20 \%$ rent mark up. The effects of the floor, in which the dwelling is located, meet our expectations: the most expensive floors are Hochparterre (raised ground floor) and the 1st floor. The cheapest dwellings were located in the cellar or in the highest, 4 th, floor, immediately below the roof. ${ }^{28}$

Locational characteristics The location of dwellings has a strong effect on their rent. The corresponding district coefficients are omitted from the tables to save space. Their impact can be best appreciated in Figure 11 depicting the distribution of quality-adjusted rents by districts. The rent for each district is obtained as a weighted average of OLS quality-adjusted rents for the corresponding districts and size classes $(1,3.5,6$, and 9 rooms) as of July 1914. As weights the structure of housing stock for respective district was used. The contours of Alt-Berlin are highlighted by a black continuous line. It can be seen that the geographical distribution of rents goes well beyond its borders. In the center of each district, the corresponding quality-adjusted annual rent per apartment and the number of announcements with rent are indicated. The highest rents are observed

\footnotetext{
${ }^{28}$ Vier Treppen hoch. BTB, August 28th, 1909, p. 49: "Die erste Etage war früher noch mehr wie heute das vornehmste Quartier des bürgerlichen Wohnhauses. Davon zeugt noch der alte Name Bel-Etage... Mit der zunehmenden Bevölkerungsdichtigkeit hat allmählich dies Vorurteil gegen die höheren Etagen nachgelassen. Trotzdem verbirgt sich heute noch häufig die erste Etage unter der Bezeichnung Hochparterre, um so auf einfache Art den Rang der übrigen Etagen um je eine Stufe zu verbesseren".
} 
in the West, especially in Wilmersdorf and Zehlendorf that already at that time were the districts inhabited by affluent people. The lowest rents are observed in the outskirts of the city. ${ }^{29}$ In Alt-Berlin, the low rents were found in Gesundbrunnen, Wedding, Prenzlauer Berg, and Friedrichshain — districts, where factories were concentrated and which were largely populated by the industrial workers. The coefficients of different isochrones provide estimates of the price of accessibility. It can be seen in Table 3 that a larger travel time is associated with significantly lower annual rent. The rent discount is especially high, when the travel time exceeds 1 hour.

Other characteristics Finally, the coefficient of the source is positive and significance. This implies that compared to BLA the BTB was addressing more affluent social classes and therefore tended to advertise more expensive apartments.

\section{Evolution of Berlin's rent before and during the World War I}

The evolution of the quality-adjusted rents is shown in Figure 9. It is the annual rent for a typical apartment of our sample — 4 rooms, 2nd floor, electric light, hot water heating, and hot water provision, located in Schöneberg district. The continuous thin black line represents the raw hedonic rent resulting from the OLS regression. It is too volatile and therefore we decided to smooth using spline function with smoothing parameter 0.6. The continuous bold blue line represents the resulting smoothed rent. A gray polygon denotes the war period. It can be seen that the rents started to fall already in June 1913, that is, more than year before the beginning of the WWI. This can be related to the crisis that struck Berlin's real-estate market in 1912, which is thoroughly described in Bernhardt (1998). However, the outbreak of the war accelerated the rent decrease. Between July 1914 and November 1915, the rents went down by $12 \%$. Since then, they started to climb up. This increase was rather slow, and in December 1917 the asking rents were still 3\% below their pre-war level.

What could have caused the rent increase? During the war, Groß-Berlin's population stagnated and started to rise only in the aftermath of the WWI. However, the last two war years saw an increased household formation through a surge in the number of marriages (see Introduction). Together with declined housing stock this should have triggered the rent increase.

In addition, the rent increase could have been caused by expansionary monetary and fiscal policy of German

\footnotetext{
${ }^{29}$ See, for example, Leyden (1933) pp. 148-154 and Bernhardt (1998) pp. 19-20.
} 
government. For example, compared to 1913, paper money volume went up already in 1914 by 1.9 times, in 1916 by 3 times, and in 1918 by 8 times. ${ }^{30}$ Likewise, in 1918, the government debt was 21 times larger than in 1913.

Nevertheless, this rent growth is dwarfed when compared to that of the prices for staple food. For instance, the average wholesale food prices in German Reich went up from 1914 through 1917 by $74 \%$. Over the same period, in Berlin, the retail prices for food increased between 16\% (wheat floor) and 289\% (eggs). The rent increase also appears to be very moderate compared to the national inflation rate, see Deutsche Bundesbank (1976). This implies that in real terms the housing rents in Berlin actually went down.

Different market segments can have different dynamics. It is known from the literature that the largest housing shortage was observed in the small (less than 3 rooms) apartments segment. ${ }^{31}$ These are the dwellings occupied by the most numerous low-income strata of population. In order to identify the segment-specific dynamics of rents we use quantile regression.

Nine different quantile regressions $(\tau=0.1,0.2, \ldots, 0.9)$ are estimated in order to obtain rent dynamics by market segments: ranging from the cheapest (1st decile) to the most expensive (9th decile) dwellings.

The homoskedasticity Wald-type test conducted across these nine conditional quantiles leads to a rejection of a joint null hypothesis that all of the conditional quantile functions have the same slope parameters at $1 \%$ significance level. When conducted for each slope parameter separately, the test allows rejecting the null for the most structural and location characteristics. Interestingly, for the coefficients at isochrones the null hypothesis cannot be rejected at $1 \%$ level meaning that the effects of accessibility are identical for cheap and expensive apartments. For the time dummies the null can only be rejected in $8.4 \%(24.3 \%)$ of the periods at $1 \%(10 \%)$ significance. The null hypothesis is mainly rejected for the latter periods, especially for 1917. This has to do with diverging dynamics of rents between the cheap and more expensive dwellings.

Figure 10 depicts the quality-adjusted rent dynamics of these segments. The rents for different segments were computed for typical dwellings located in Schöneberg district, in 20 to 40 travel minutes from Alexanderplatz. The number of rooms in a dwelling belonging to each segment was determined based on the corresponding quantiles. Thus, the number of rooms in small dwellings is 2 , while in the large ones - 6 . The upper panel

\footnotetext{
${ }^{30}$ As can be seen from various issues of the Statistical Yearbook of the German Reich (Statistisches Jahrbuch für das Deutsche Reich).

${ }^{31}$ See, for example, Führer (1995), p. 23.
} 
shows the segment-specific rents in marks: the vertical axis has a logarithmic scale in order to make the differences between various time series visible. The lower panel reports the segment-specific rent indices. They were obtained by dividing the rents in marks through their July 1914 levels. It can be seen that the qualityadjusted rents experienced a substantial decrease. It started already in the April 1913 for the most market segments. For all segments, the decline lasted until the beginning of 1916 and was particularly pronounced for small apartments. While the rents for expensive apartments went down by 5-6\%, those for cheap dwellings declines by almost 20\%. It is symptomatic that in 1916 the vacancy rate attained its local maximum, as can be seen in Figure 2.

In the middle of the war, driven by a strong demand increase and shrinking supply, the tendency for the whole market was reversed. The dynamics were different for different market segments. The largest rent increase - about $16 \%$ compared to the lowest value attained in 1916 - was in the segment of middle apartments. The rents for large dwellings went up by $5 \%$ and thus returned to the pre-war level. Finally, the rents for cheap apartments after having followed the general upward trend for about a year, started to decrease in July 1917 and fell to $77 \%$ of the pre-war level.

However, in the segment of cheap apartments, the rents continued to fall at least till the end of 1917 . A possible explanation could be a filtering down effect. It means that due to a shortage of resources (the bulk of resources was diverted towards military industry, many dwellings stayed empty, while the tenant occupied dwellings brought lower revenues due to decreased rents) the maintenance of housing was neglected and many dwellings downgraded. Thus, the supply of expensive dwellings went down, whereas that of cheap dwellings went up. Moreover, the volatility of the cheap rents was much higher than that of the rents for more expensive apartments. One explanation can be found in Reich (1912), p. 7. According to her, the lower-income persons are more exposed to the business cycle fluctuations. Therefore, by making decision on creating a family or migrating — the factors that directly affect the housing demand - they are more responsive to the fluctuations of the overall economic situation. 


\section{Conclusion}

This paper investigated the monthly housing rent dynamics in Berlin between January 1909 and December 1917. The analysis was based on a unique data set of asking rents containing about 14,000 observations. The data were collected from newspaper announcements and georeferenced using the addresses and a set of historical maps. This permitted to estimate the quality-adjusted rents as a function of both structural and locational characteristics of the advertised dwellings.

We found a substantial decrease of the quality-adjusted rents in Berlin, which started already in 1914, even before the World War I began. The decline lasted until the beginning of 1916 and was particularly pronounced for small apartments. In the penultimate war year, driven by a strong demand increase, the tendency for the whole market was reversed. However, in the segment of cheap apartments, the rents continued to fall at least till the end of 1917. Moreover, the volatility of the cheap rents was much higher than that of the rents for more expensive apartments.

Compared with a much stronger overall price increase, especially that of the staple food, the rent increase turns out to be very moderate. In fact, during the war, when neither rent regulations nor tenants' protection were still in place, the real rents went down. This suggests a high degree of downward and low degree of upward flexibility of the housing rents in the absence of regulations. Unfortunately, striving at establishing social justice, the subsequent regulations put end to the market freedom and for many years destroyed the signaling function of the rents. This made necessary an even deeper involvement of the state in the housing market associated with the corresponding socioeconomic costs and distortions.

The estimates of the (asking) housing rents suggested in this paper can shed more light on the evolution of the rental housing cost in particular and the cost of living in general in a big German city before and during the First World War. Thus, they allow bridging a large gap in the data. As a consequence, our understanding of the functioning of the market economy in war conditions can be substantially improved. The lessons learned 100 years ago can still be useful today against the background of the recent surge of the state activism in the housing market, which is experienced by some countries, like France or Germany. 


\section{References}

Achilles, A., M. Grieff, F. André, F. Ritgen, O. Strecker, and K. Unzner (Eds.) (1909). Bürgerliches Gesetzbuch nebst Einführungsgesetz / Mit Einleitung, Anmerkungen und Sachregister nach dem Tode des ersten Herausgebers dr. A. Achilles. J. Guttentag.

Ahlfeldt, G. M. and N. Wendland (2011). Fifty years of urban accessibility: The impact of the urban railway network on the land gradient in Berlin 1890-1936. Regional Science and Urban Economics 41(2), 77-88.

Ascher, S. (1917). Die Wohnungsmieten in Berlin von 1880-1910. Carl Heymanns Verlag: Erlangen.

Bernhardt, C. (1998). Bauplatz Groß-Berlin. Wohnungsmärkte, Terraingewerbe und Kommunalpolitik im Städtewachstum der Hochindustrialisierung (1871-1918). Berlin, New York: Walter de Gruyter.

Brander, S. (1984). Wohnungspolitik als Sozialpolitik. Theoretische Konzepte und praktische Ansätze in Deutschland bis zum Ersten Weltkrieg. Duncker \& Humblot: Berlin.

Calcagno, V. and C. de Mazancourt (2010). glmulti: An R package for easy automated model selection with (generalized) linear models. Journal of Statistical Software 34(i12), 1-29.

Deutsche Bundesbank (1976). Deutsches Geld- und Bankwesen in Zahlen 1876-1975: Statistischer Beiband zur Bundesbank - Festschrift, Währung und Wirtschaft 1876-1975. Deutsche Bundesbank.

Dussel, K. (2011). Deutsche Tagespresse im 19. und 20. Jahrhundert. LIT Verlag Berlin.

Führer, K. C. (1995). Mieter, Hausbesitzer, Staat und Wohnungsmarkt. Wohnungsmangel und Wohnungszwangswirtschaft in Deutschland 1914-1960. Franz Steiner Verlag: Stuttgart.

International Labour Office (1924). European housing problems since the war. Imprimeries réunies S.A.: Geneva.

Kaeber, E. (1921). Berlin im Weltkriege. Fünf Jahre städtischer Kriegsarbeit. Trowitzsch und Sohn: Berlin.

Kholodilin, K. A. and D. Ulbricht (2014). Mietpreisbremse: Wohnungsmarktregulierung bringt mehr Schaden als Nutzen. DIW Wochenbericht 81(15), 319-327.

Koenker, R. (2005). Quantile regression. Cambridge University Press. 
Koenker, R. (2012). Quantile regression in R: A vignette.

Koenker, R. W. and G. Bassett (1978). Regression quantiles. Econometrica 46(1), 33-50.

Königliche Eisenbahndirektion Berlin (1912). Fahrplan für den Berliner Stadt-, Ring- und Vorortverkehr. Gültig vom 1. Oktober 1912. Druck von W. Bürgenstein.

Leyden, F. (1933). Groß-Berlin. Geographie der Weltstadt. Ferdinand Hirt in Breslau.

Margo, R. A. (1996). The rental price of housing in New York City, 1830-1860. The Journal of Economic History $56(3)$, 605-625.

Olsen, E. O. (1969). A competitive theory of the housing market. American Economic Review 59(4), $612-22$.

Pebesma, E. J. (2014). gstat user's manual.

Rees, A. (1961). Real wages in manufacturing, 1890-1914. Princeton: Princeton University Press.

Reich, E. (1912). Der Wohnungsmarkt in Berlin von 1840-1910. Verlag von Duncker \& Humblot.

Riedel, J. (1911). Anregungen für die Konstruktion und die Verwendung von Isochronenkarten. Druck von Thomas \& Hubert.

Rigobon, R. and T. M. Stoker (2009). Bias from censored regressors. Journal of Business and Economic Statistics 27(3), 340-353.

Silbergleit, H. (Ed.) (1913). Statistisches Jahrbuch der Stadt Berlin. 32. Jahrgang, enthaltend die Statistik der Jahre 1908 bis 1911 sowie Teile von 1912. Verlag von P. Stankiewicz' Buchdruckerei GmbH: Berlin.

Silbergleit, H. (Ed.) (1920). Statistisches Jahrbuch der Stadt Berlin. 34. Jahrgang, enthaltend die Statistik der Jahre 1915 bis 1919 sowie Teile von 1920. Verlag von P. Stankiewicz' Buchdruckerei GmbH: Berlin.

Stöber, R. (2014). Deutsche Pressegeschichte. UVK Verlagsgesellschaft: Konstanz. 


\section{Appendix}

Table 1: Descriptive statistics of numeric variables

\begin{tabular}{|c|c|c|c|c|c|c|c|c|c|c|c|}
\hline Variable & Levels & $\mathbf{n}$ & Min & $q_{1}$ & $\widetilde{\mathbf{x}}$ & $\overline{\mathbf{x}}$ & $q_{3}$ & $\operatorname{Max}$ & $\mathbf{s}$ & IQR & \#NA \\
\hline \multirow{2}{*}{ Rent } & Berliner Lokalanzeiger & 6608 & 22 & 450 & 720 & 853.0 & 1100 & 6500 & 585.7 & 650 & 1059 \\
\hline & all & 11666 & 22 & 576 & 900 & 1072.3 & 1375 & 8000 & 760.8 & 799 & 1962 \\
\hline \multirow{2}{*}{ Room } & Berliner Tageblatt und Handels-Zeitung & 5873 & 1 & 3 & 4 & 4.6 & 6 & 22 & 1.9 & 3 & 88 \\
\hline & all & 13215 & 0 & 3 & 4 & 3.9 & 5 & 22 & 1.8 & 2 & 413 \\
\hline \multirow[t]{2}{*}{ Year } & Berliner Lokalanzeiger & 7667 & 1909 & 1910 & 1912 & 1912.3 & 1914 & 1917 & 2.6 & 4 & 0 \\
\hline & Berliner Tageblatt und Handels-Zeitung & 5961 & 1909 & 1910 & 1912 & 1912.3 & 1914 & 1917 & 2.3 & 4 & 0 \\
\hline \multirow{2}{*}{ Month } & Berliner Tageblatt und Handels-Zeitung & 5961 & 1 & 3 & 6 & 5.6 & 8 & 12 & 3.3 & 5 & 0 \\
\hline & all & 13628 & 1 & 3 & 6 & 5.8 & 9 & 12 & 3.4 & 6 & 0 \\
\hline \multirow[t]{3}{*}{ Day } & Berliner Lokalanzeiger & 7667 & 1 & 3 & 5 & 6.7 & 7 & 31 & 6.2 & 4 & 0 \\
\hline & Berliner Tageblatt und Handels-Zeitung & 5961 & 1 & 7 & 14 & 15.0 & 24 & 31 & 9.3 & 17 & 0 \\
\hline & all & 13628 & 1 & 4 & 7 & 10.3 & 16 & 31 & 8.7 & 12 & 0 \\
\hline
\end{tabular}


Table 2: Descriptive statistics of nominal variables

\begin{tabular}{|c|c|c|c|c|c|c|c|}
\hline Variable & Levels & $\mathbf{n}_{\text {large }}$ & \%large & $\mathbf{n}_{\text {small }}$ & $\%_{\text {small }}$ & $\mathbf{n}_{\text {all }}$ & $\%_{\text {all }}$ \\
\hline \multirow[t]{8}{*}{ Floor } & & 4549 & 45.1 & 2313 & 73.9 & 7176 & 52.7 \\
\hline & 1 & 1644 & 16.3 & 226 & 7.2 & 1911 & 14.0 \\
\hline & 2 & 1428 & 14.2 & 160 & 5.1 & 1603 & 11.8 \\
\hline & 3 & 1210 & 12.0 & 145 & 4.6 & 1367 & 10.0 \\
\hline & 4 & 370 & 3.7 & 115 & 3.7 & 492 & 3.6 \\
\hline & hochparterre & 509 & 5.0 & 35 & 1.1 & 549 & 4.0 \\
\hline & parterre & 374 & 3.7 & 137 & 4.4 & 530 & 3.9 \\
\hline & all & 10084 & 100.0 & 3131 & 100.0 & 13628 & 100.0 \\
\hline \multirow[t]{3}{*}{ Lift } & 0 & 9380 & 93.0 & 3112 & 99.4 & 12903 & 94.7 \\
\hline & 1 & 704 & 7.0 & 19 & 0.6 & 725 & 5.3 \\
\hline & all & 10084 & 100.0 & 3131 & 100.0 & 13628 & 100.0 \\
\hline \multirow[t]{5}{*}{ Heating } & & 8879 & 88.0 & 2972 & 94.9 & 12262 & 90.0 \\
\hline & Central & 532 & 5.3 & 54 & 1.7 & 588 & 4.3 \\
\hline & Vapor & 12 & 0.1 & 2 & 0.1 & 14 & 0.1 \\
\hline & Warm water & 661 & 6.5 & 103 & 3.3 & 764 & 5.6 \\
\hline & all & 10084 & 100.0 & 3131 & 100.0 & 13628 & 100.0 \\
\hline \multirow[t]{3}{*}{ Warm water } & 0 & 8034 & 79.7 & 2848 & 91.0 & 11286 & 82.8 \\
\hline & 1 & 2050 & 20.3 & 283 & 9.0 & 2342 & 17.2 \\
\hline & all & 10084 & 100.0 & 3131 & 100.0 & 13628 & 100.0 \\
\hline \multirow[t]{3}{*}{ Electric light } & 0 & 8737 & 86.6 & 3030 & 96.8 & 12172 & 89.3 \\
\hline & 1 & 1347 & 13.4 & 101 & 3.2 & 1456 & 10.7 \\
\hline & all & 10084 & 100.0 & 3131 & 100.0 & 13628 & 100.0 \\
\hline \multirow[t]{3}{*}{ Bath } & 0 & 6316 & 62.6 & 2376 & 75.9 & 9054 & 66.4 \\
\hline & 1 & 3768 & 37.4 & 755 & 24.1 & 4574 & 33.6 \\
\hline & all & 10084 & 100.0 & 3131 & 100.0 & 13628 & 100.0 \\
\hline \multirow[t]{3}{*}{ Kitchen } & 0 & 9134 & 90.6 & 1695 & 54.1 & 11229 & 82.4 \\
\hline & 1 & 950 & 9.4 & 1436 & 45.9 & 2399 & 17.6 \\
\hline & all & 10084 & 100.0 & 3131 & 100.0 & 13628 & 100.0 \\
\hline \multirow[t]{3}{*}{ Chamber } & 0 & 9762 & 96.8 & 2929 & 93.5 & 13081 & $\overline{996.0}$ \\
\hline & 1 & 322 & 3.2 & 202 & 6.4 & 547 & 4.0 \\
\hline & all & 10084 & 100.0 & 3131 & 100.0 & 13628 & 100.0 \\
\hline \multirow[t]{3}{*}{ Corridor } & 0 & 10009 & 99.3 & 2993 & 95.6 & 13414 & 98.4 \\
\hline & 1 & 75 & 0.7 & 138 & 4.4 & 214 & 1.6 \\
\hline & all & 10084 & 100.0 & 3131 & 100.0 & 13628 & 100.0 \\
\hline \multirow[t]{3}{*}{ Maid's room } & 0 & 8944 & 88.7 & 3066 & 97.9 & 12420 & 91.1 \\
\hline & 1 & 1140 & 11.3 & 65 & 2.1 & 1208 & 8.9 \\
\hline & all & 10084 & 100.0 & 3131 & 100.0 & 13628 & 100.0 \\
\hline \multirow[t]{3}{*}{ Vestibule } & 0 & 9878 & 98.0 & 3123 & 99.7 & 13411 & 98.4 \\
\hline & 1 & 206 & 2.0 & 8 & 0.3 & 217 & 1.6 \\
\hline & all & 10084 & 100.0 & 3131 & 100.0 & 13628 & 100.0 \\
\hline \multirow[t]{3}{*}{ Balcony } & 0 & 7795 & 77.3 & 2488 & 79.5 & 10626 & 78.0 \\
\hline & 1 & 2289 & 22.7 & 643 & 20.5 & 3002 & 22.0 \\
\hline & all & 10084 & 100.0 & 3131 & 100.0 & 13628 & 100.0 \\
\hline \multirow[t]{3}{*}{ Bay window } & 0 & 9636 & 95.6 & 3110 & 99.3 & 13146 & 96.5 \\
\hline & 1 & 448 & 4.4 & 21 & 0.7 & 482 & 3.5 \\
\hline & all & 10084 & 100.0 & 3131 & 100.0 & 13628 & 100.0 \\
\hline \multirow[t]{3}{*}{ Loggia } & 0 & 9313 & 92.3 & 3006 & 96.0 & 12705 & 93.2 \\
\hline & 1 & 771 & 7.6 & 125 & 4.0 & 923 & 6.8 \\
\hline & all & 10084 & 100.0 & 3131 & 100.0 & 13628 & 100.0 \\
\hline \multirow[t]{3}{*}{ Garden } & 0 & 9717 & 96.4 & 3053 & 97.5 & 13172 & 96.7 \\
\hline & 1 & 367 & 3.6 & 78 & 2.5 & 456 & 3.4 \\
\hline & all & 10084 & 100.0 & 3131 & 100.0 & 13628 & 100.0 \\
\hline \multirow[t]{3}{*}{ Furnished } & 0 & 9801 & 97.2 & 2882 & 92.0 & 13081 & 96.0 \\
\hline & 1 & 283 & 2.8 & 249 & 8.0 & 547 & 4.0 \\
\hline & all & 10084 & 100.0 & 3131 & 100.0 & 13628 & 100.0 \\
\hline Source & Berliner Lokalanzeiger & 4795 & 47.5 & 2547 & 81.3 & 7667 & $\overline{56.3}$ \\
\hline & Berliner Tageblatt und Handels-Zeitung & 5289 & 52.5 & 584 & 18.6 & 5961 & 43.7 \\
\hline & all & 10084 & 100.0 & 3131 & 100.0 & 13628 & 100.0 \\
\hline
\end{tabular}


Table 3: Estimation results of OLS and quantile regressions

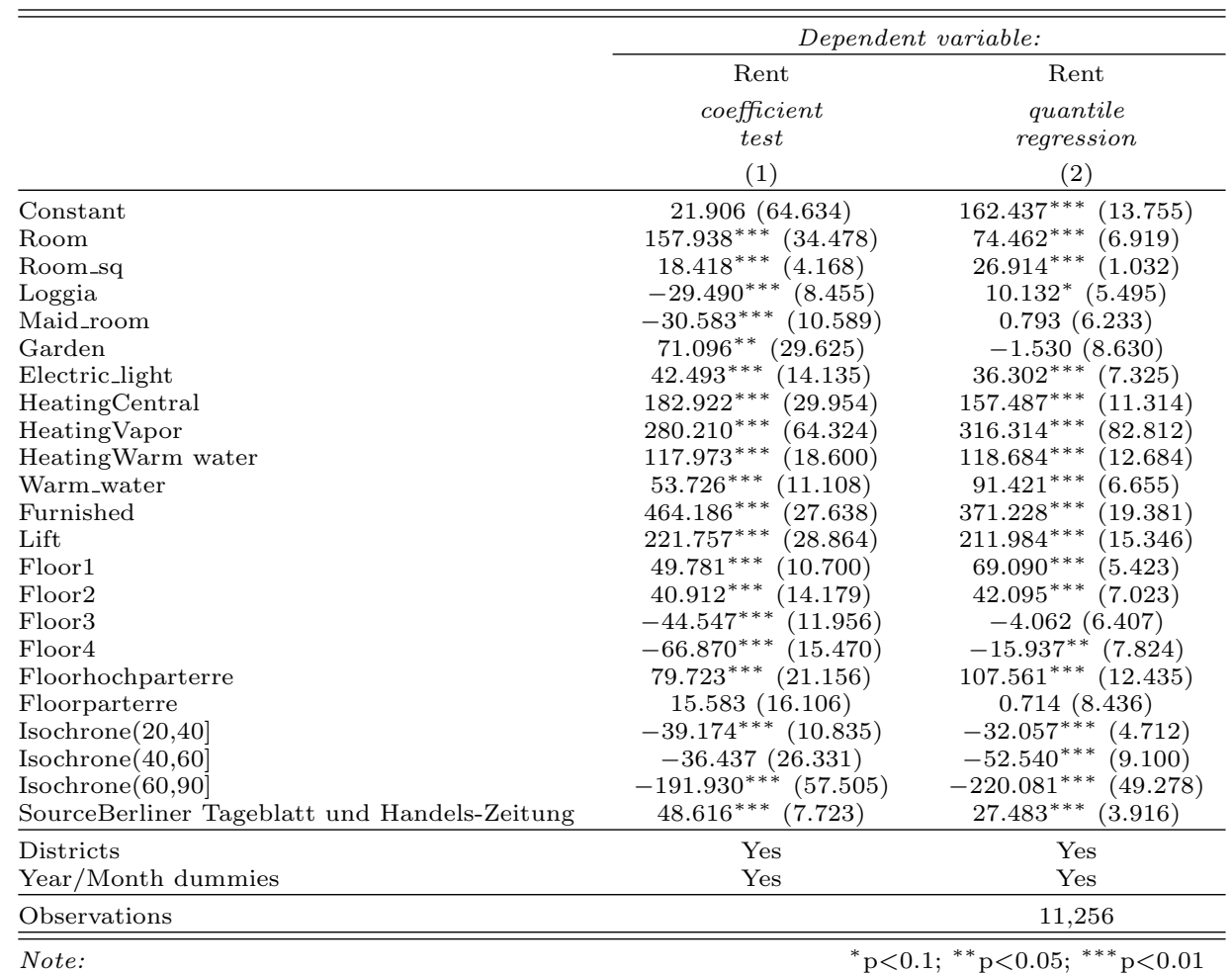


Figure 1: Housing market shocks during the World War I

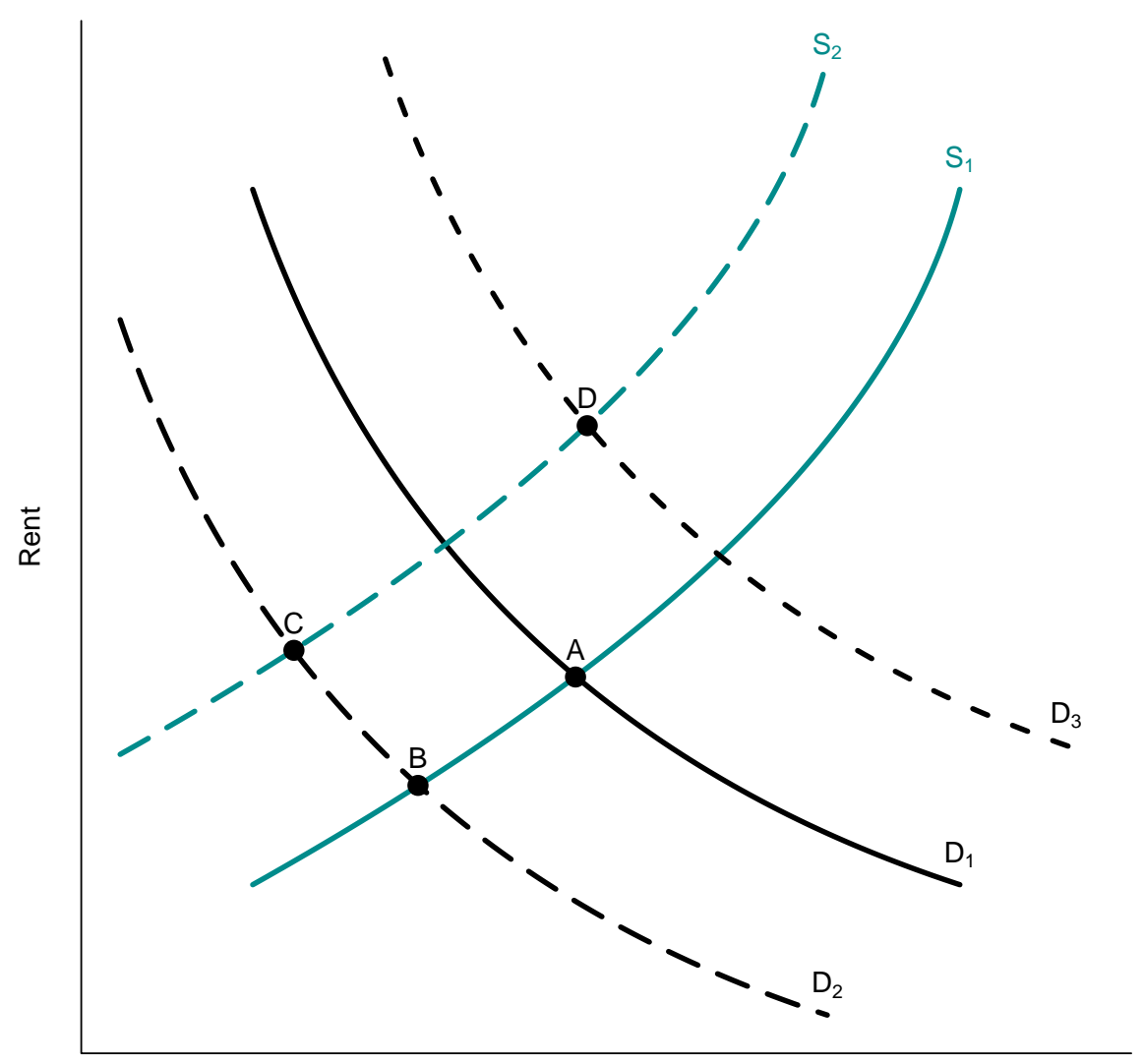

Housing stock 
Figure 2: Housing vacancy rate in Berlin, 1872-1939

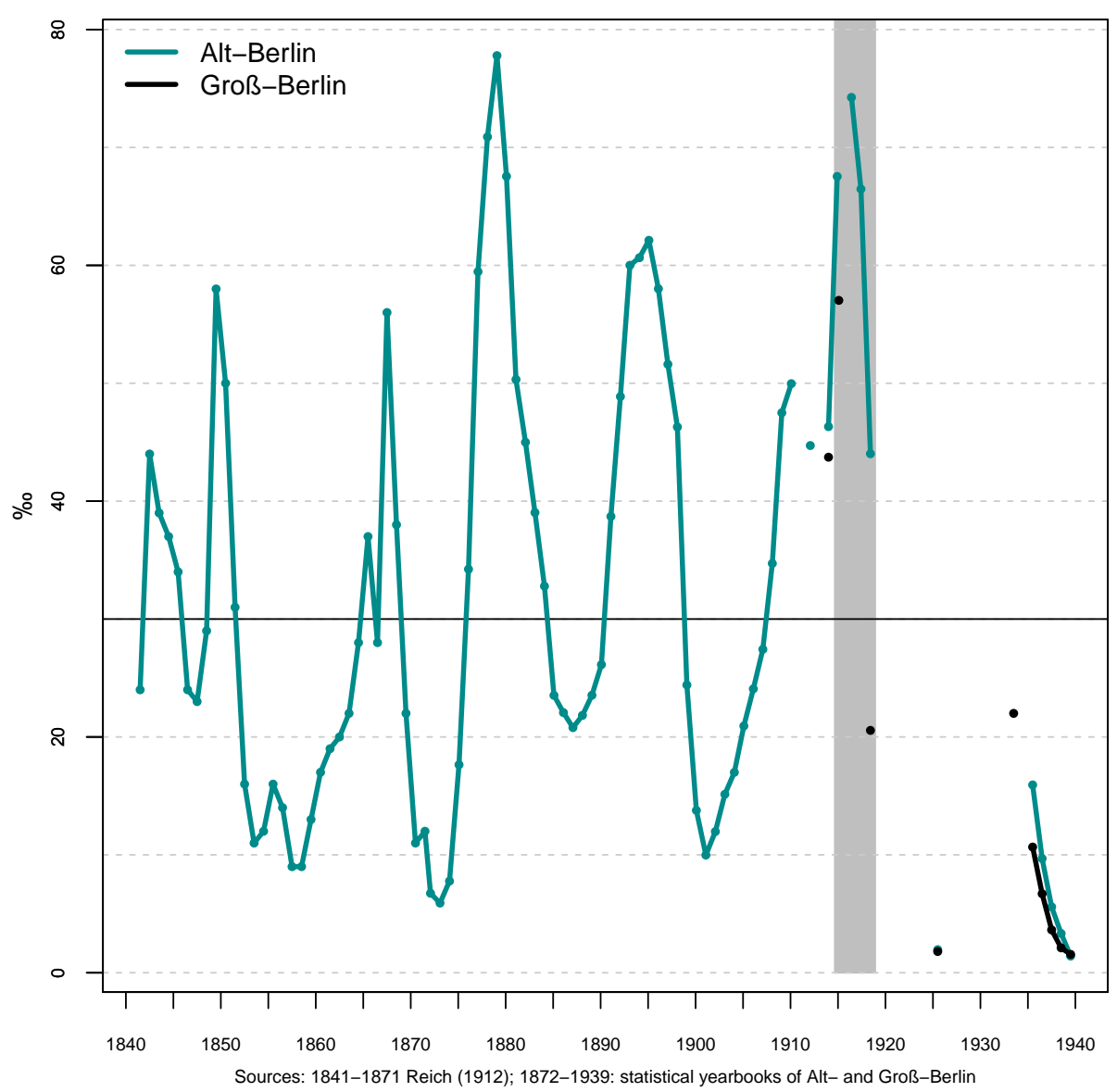


Figure 3: Data availability by newspaper

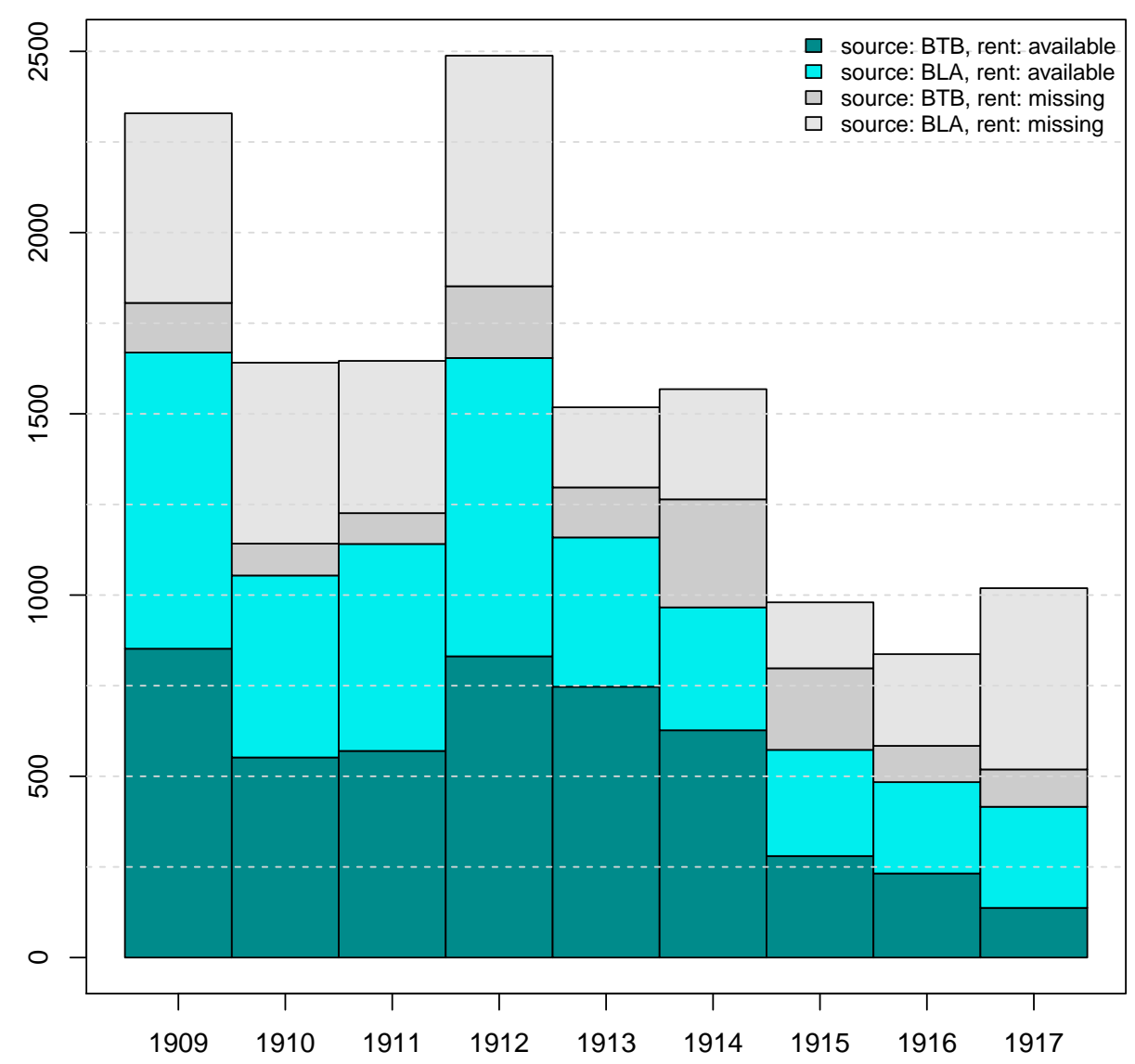


Figure 4: Spatial distribution of advertised dwellings

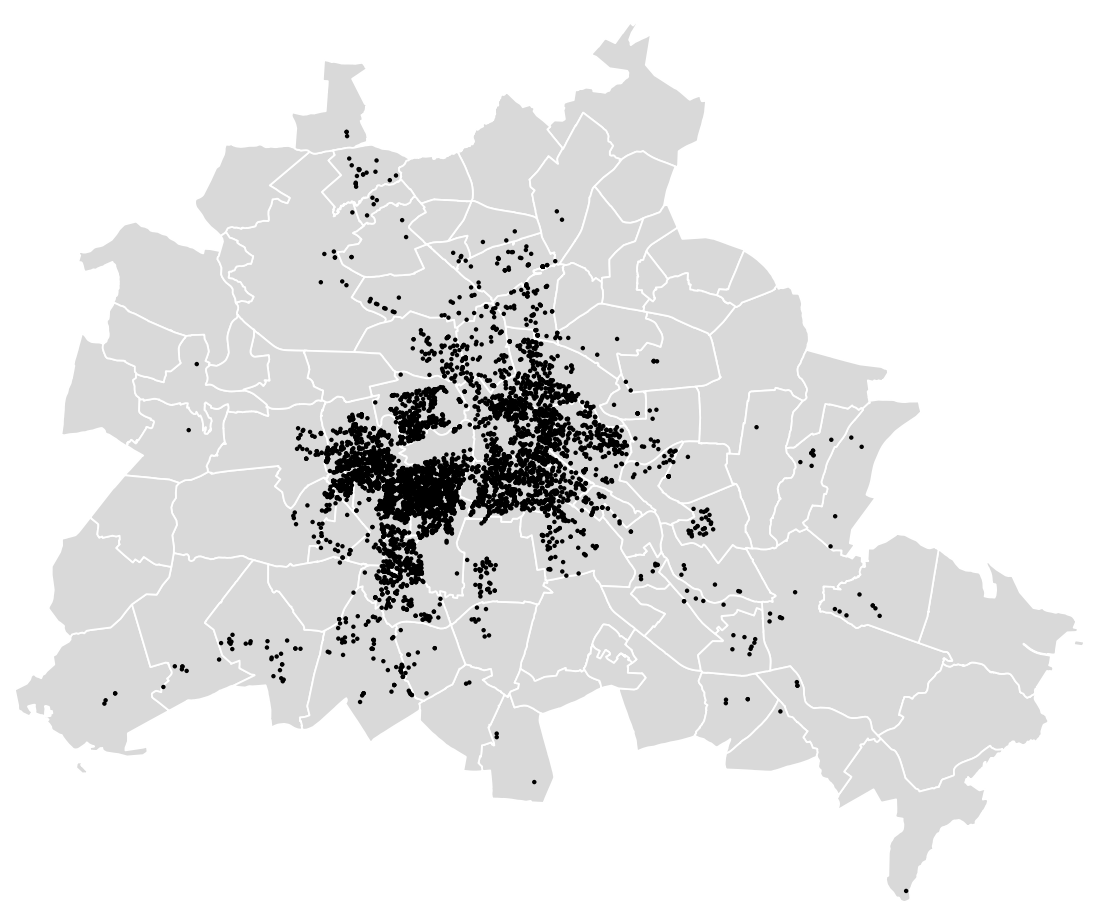


Figure 5: Isochrones of underground, city, and suburban railways for Alexanderplatz, 1912-1914

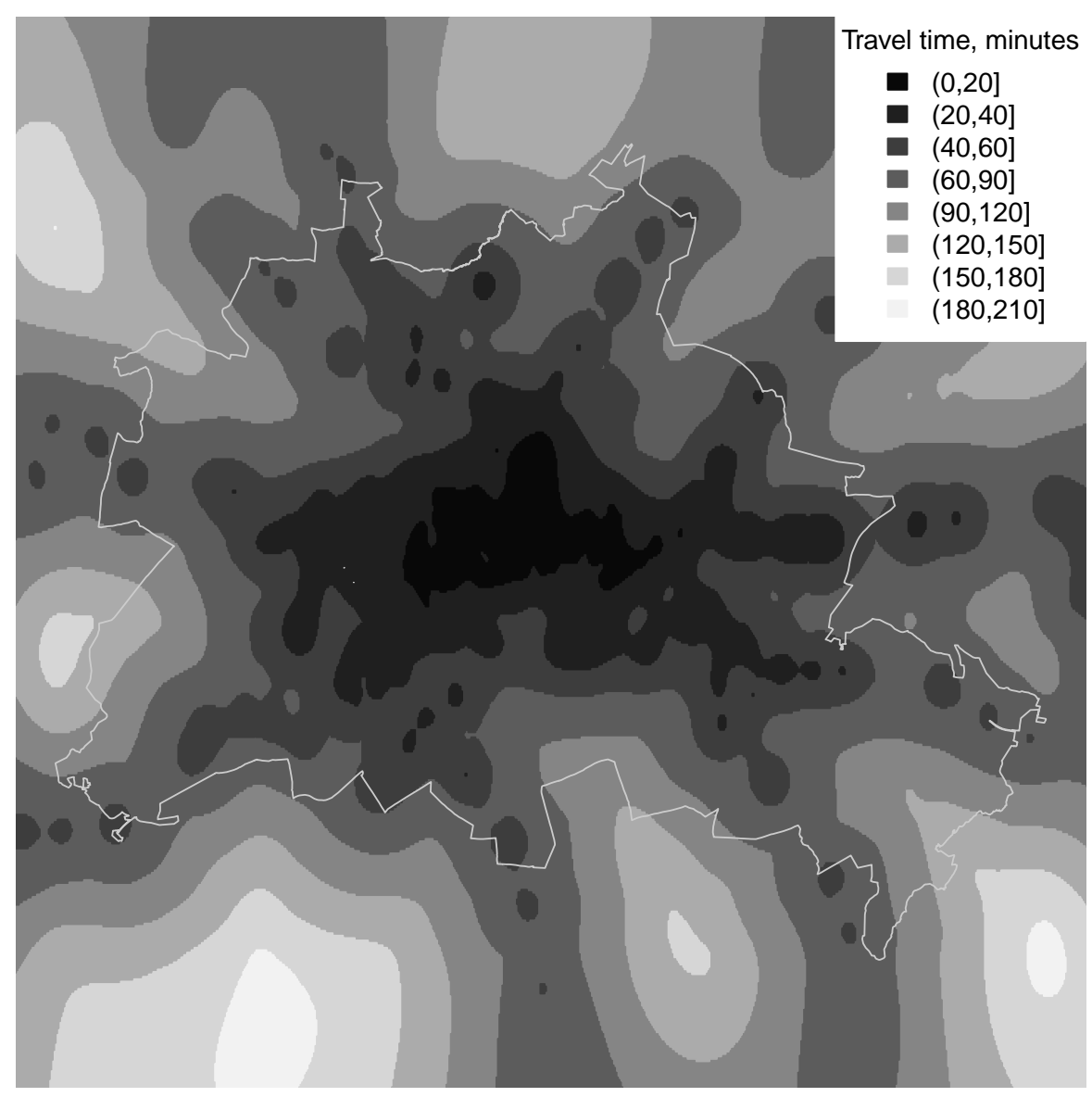


Figure 6: Distribution of Berlin's dwellings by number of habitable rooms: official data and newspapers

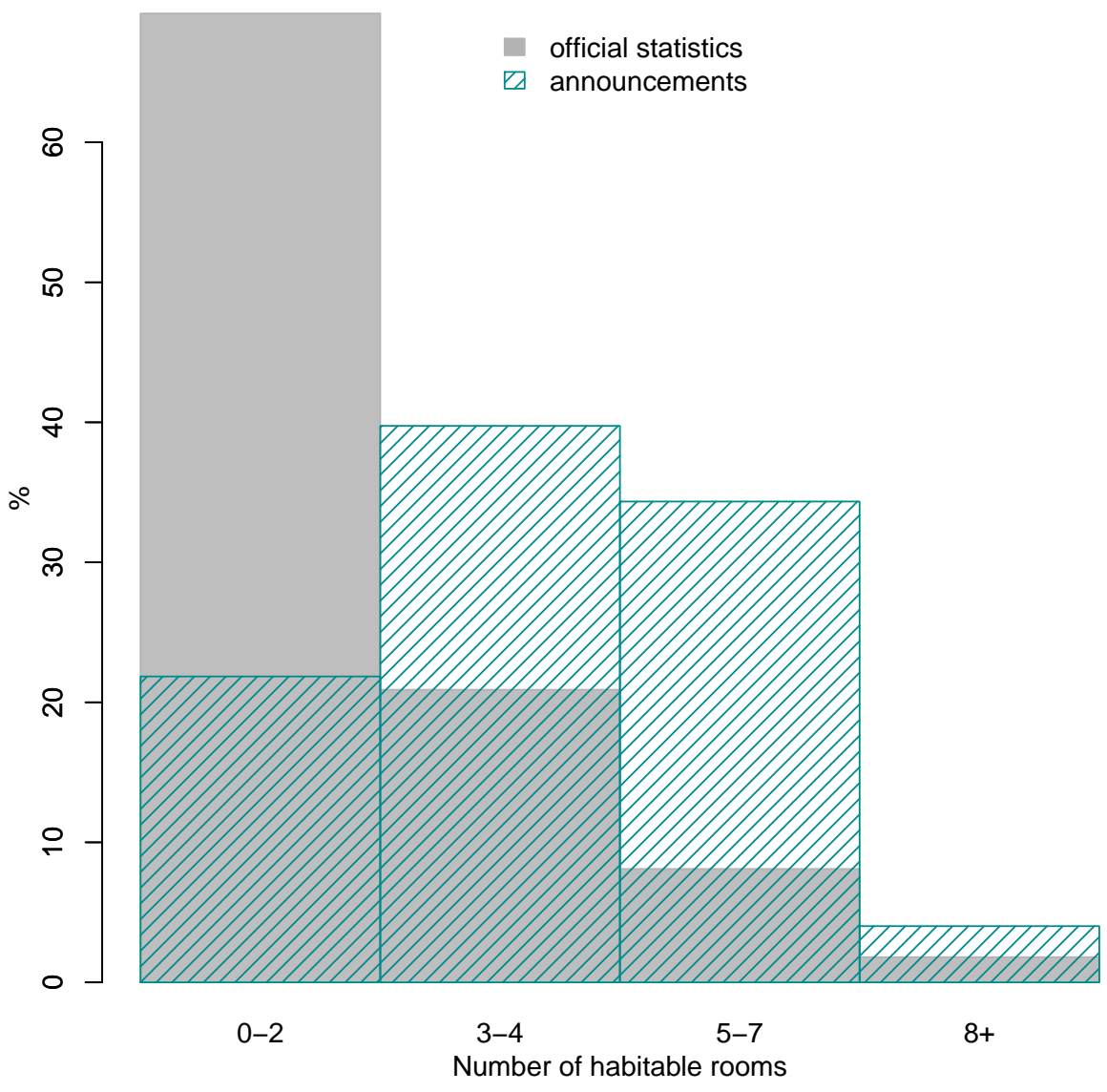

Sources: Statistisches Amt der Stadt Berlin (1924); announcements; own calculations. 
Figure 7: Comparison of housing rents by apartment size: official data and newspapers

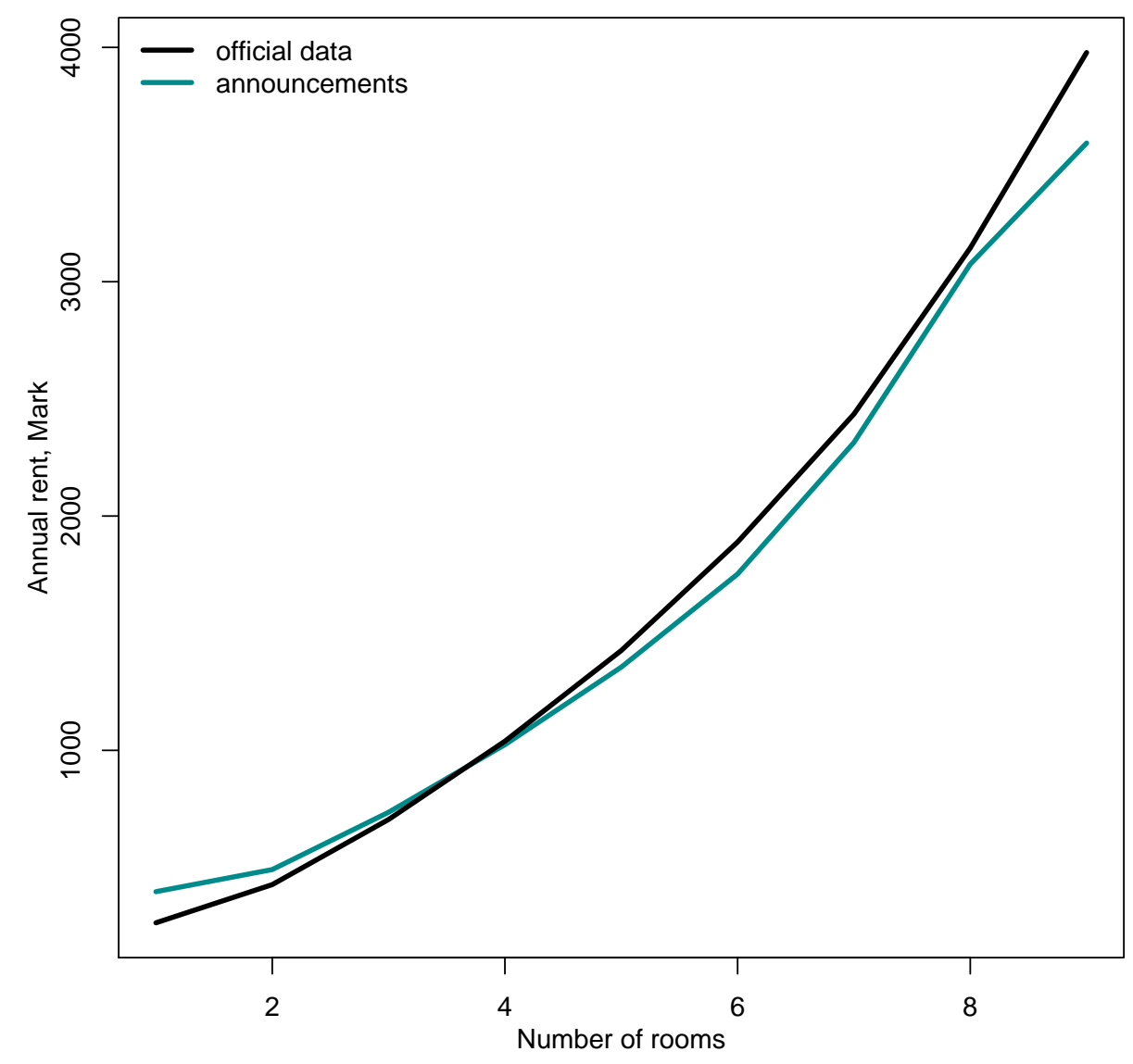

Sources: Ascher (1917); announcements; own calculations. 
Figure 8: Distribution of Berlin's rental dwellings by districts: official data and newspapers

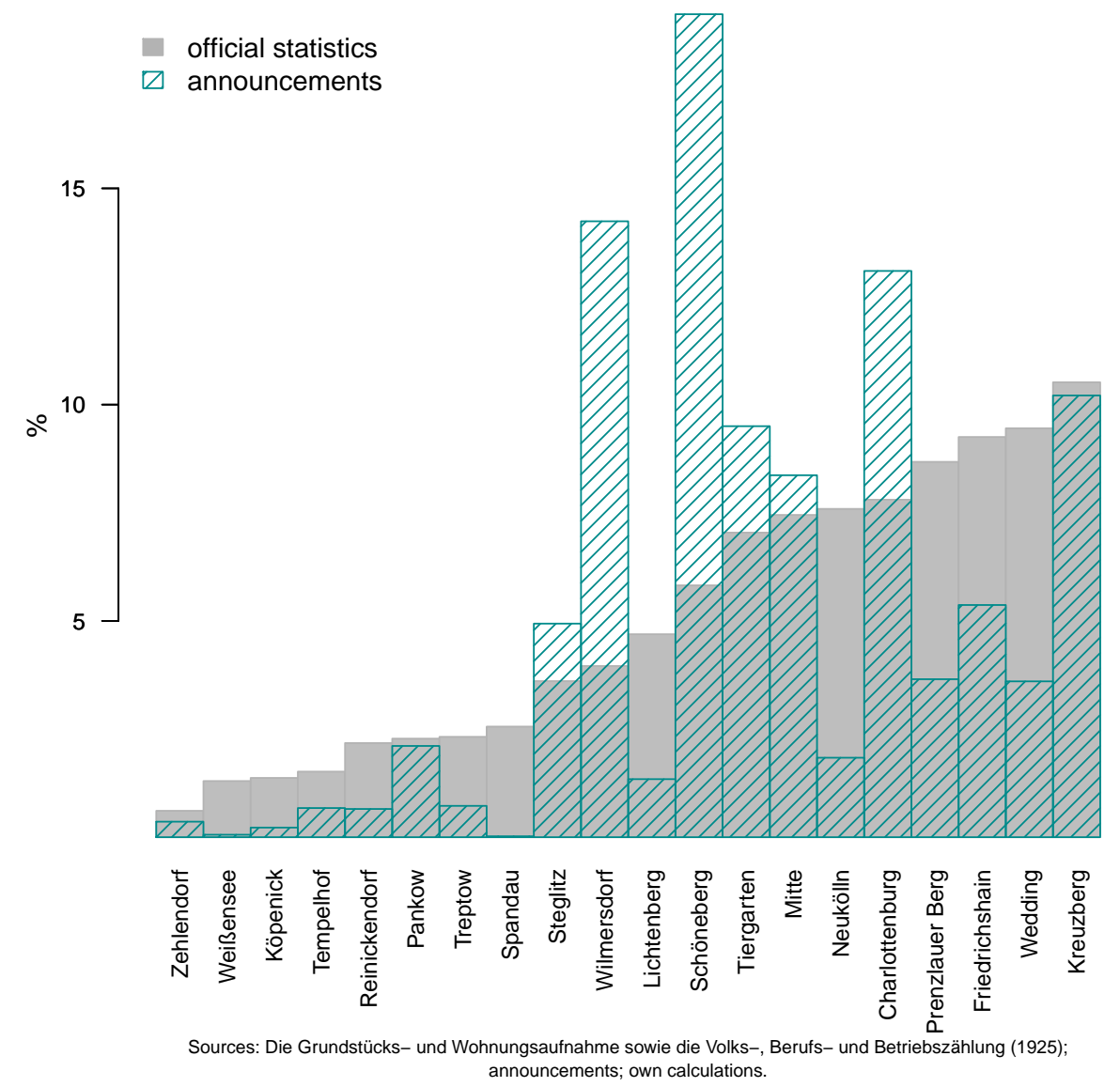


Figure 9: Quality-adjusted housing rent in Berlin, 1909-1917

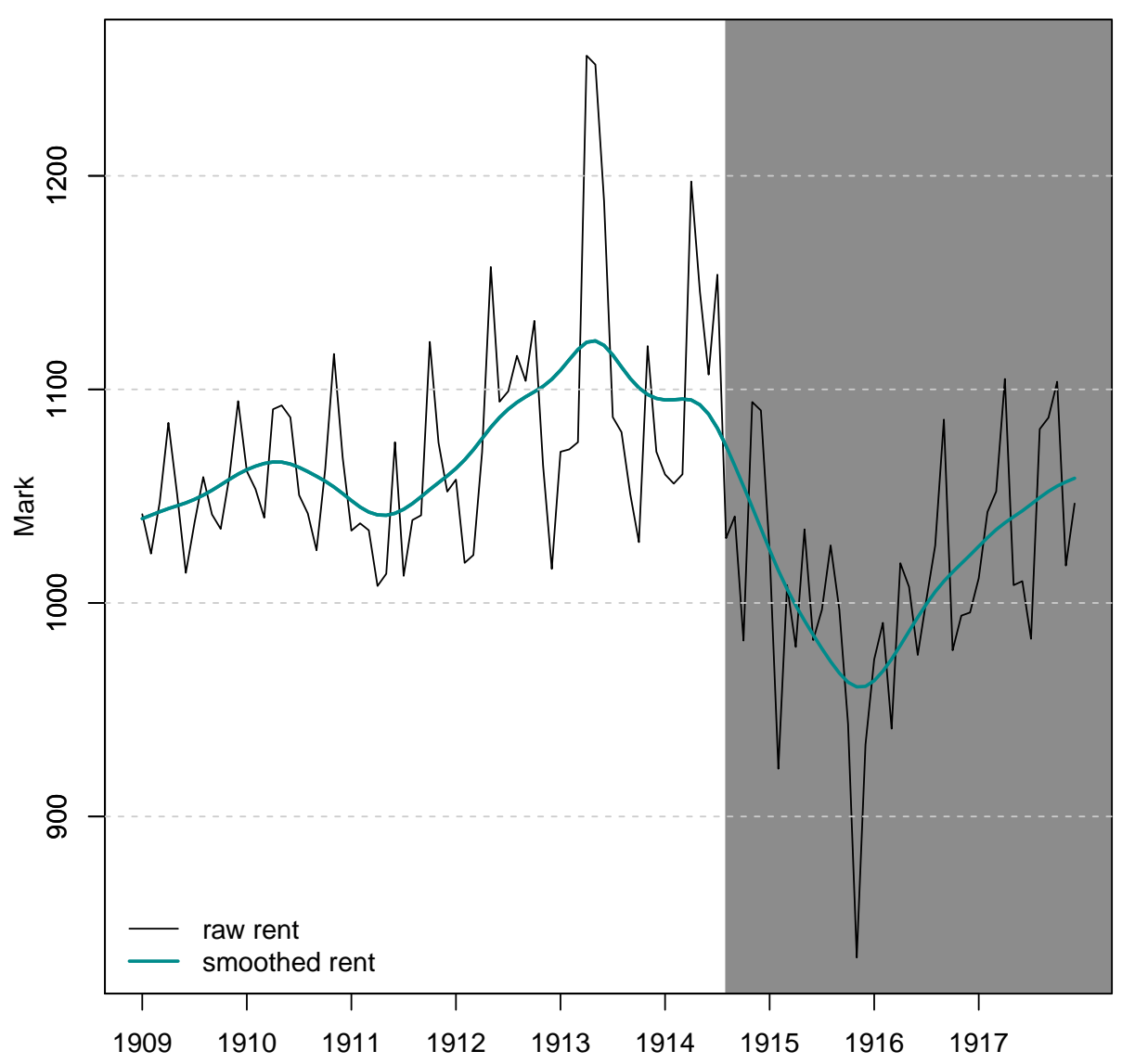


Figure 10: Dynamics of quality-adjusted housing rent in Berlin by segments, 1909-1917 a) rents in Marks

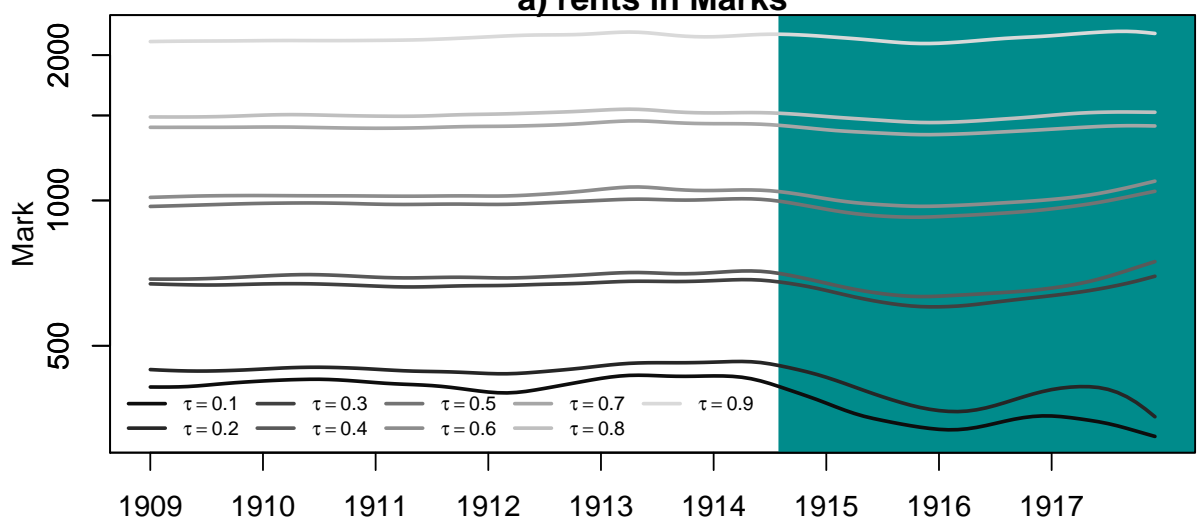

b) rents in \%

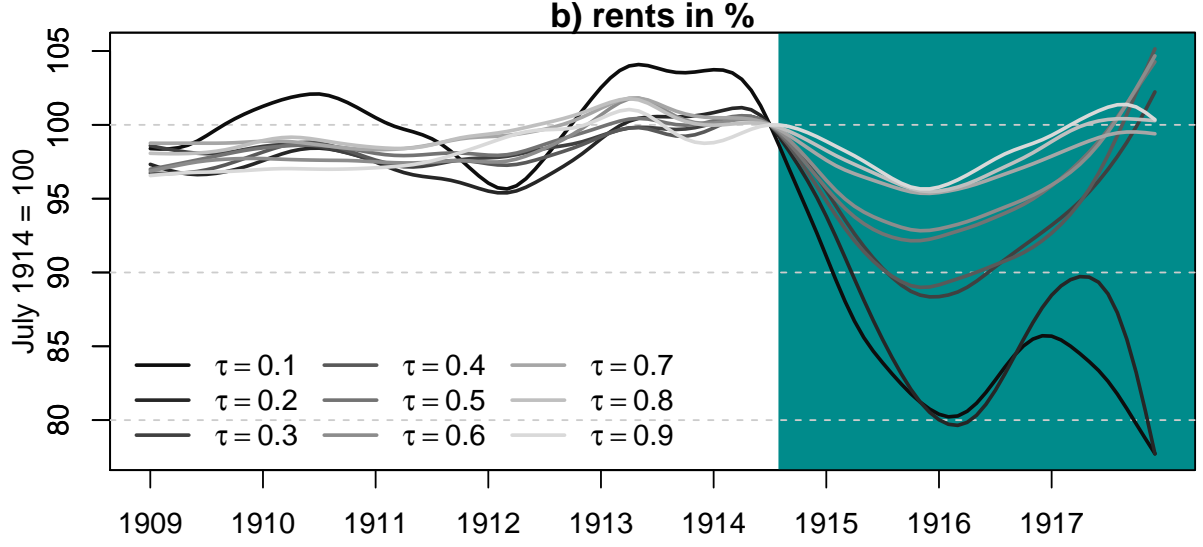


Figure 11: Geographical distribution of quality-adjusted rent in Berlin, July 1914

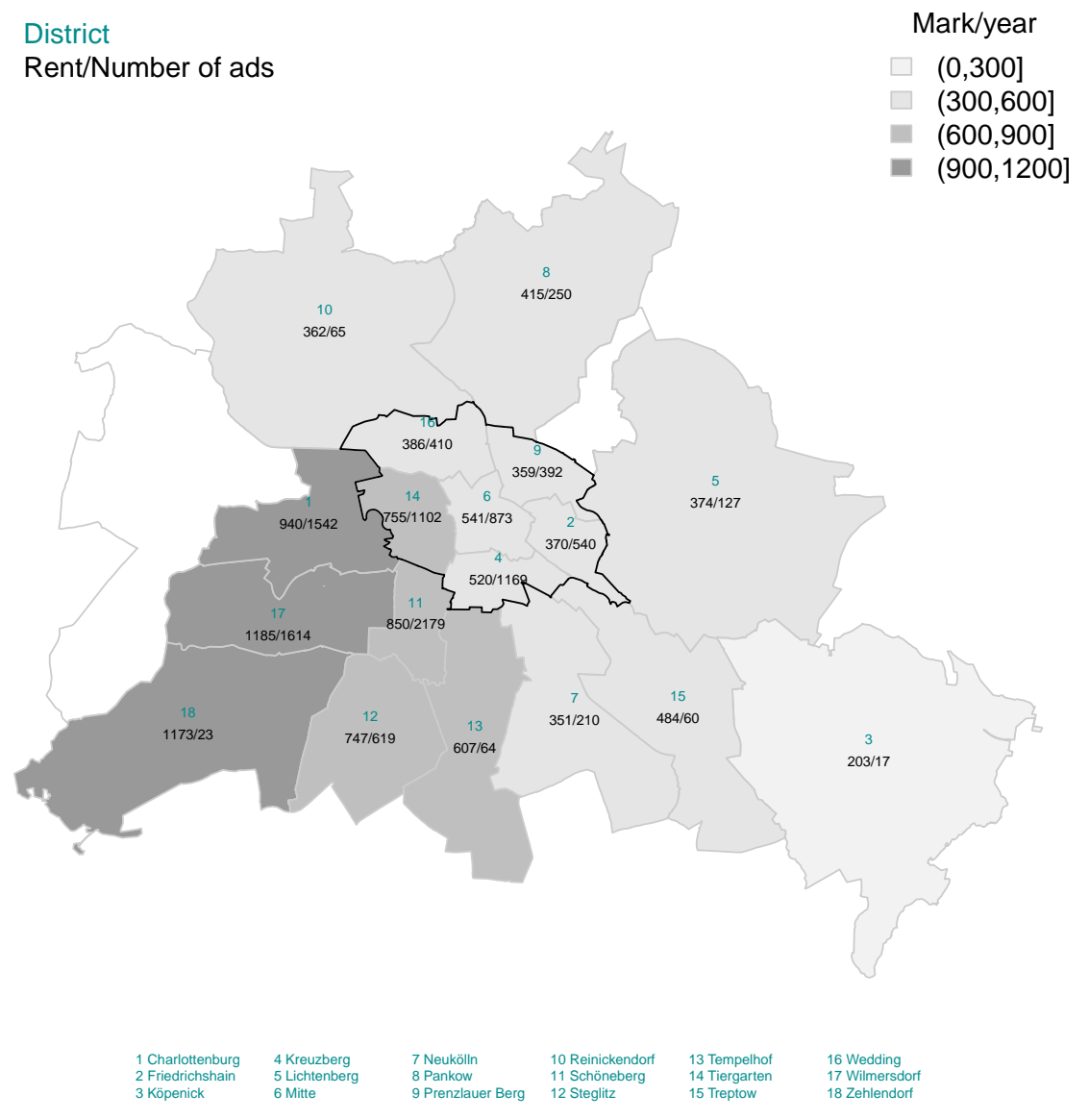

